\title{
SOCIAL AND ECONOMIC BACKGROUND OF THE SMALL LOAN PROBLEM
}

\author{
ROBERT W. KRLSO*
}

The small loan problem in the United States has many aspects. The term is so general and all-embracing as to call for more specific definition. To the legislator it is the riddle of checking extortionate charges for the use of money, and of building up safeguards for the borrower. To the lender it is a question of safe investment at a minimum of loss and a maximum of profit. To the necessitous borrower with a family it is the hard task of finding credit withdut thereby making himself worse off than before. If the topic is to be viewed from the angle of society as a whole, it will be needful to explore and interpret the economic and social setting which gives rise to cash borrowing and in which the transaction is carried out. That is the purpose of this article. It will be found necessary to inquire into the economic status of the borrower, both before and after the loan, but more particularly into the conditions which bring him to the lender. Unfortunately, the social consequences of his borrowing can be only guessed at, as research has revealed little in that sector of the problem. It is the borrower particularly who is the small loans public. He is the element in society upon which the operation of cash lending has its effect. While it is pertinent to inquire why and to what extent he borrows a small loan, the real question at the bottom of this topic is: "Must he borrow, and what does the borrowing do to him?"

\section{Small Loans a Family Problem}

There is a further important consideration to be noted in our definition-the borrower, who sounds like a lone man seeking and obtaining a loan of money, usually is in reality a family. Some $90 \%$ of all cash loans are made to family men or to married couples. It is the family man, who, for the most part, is in necessitous circumstances. It was a sage observation of Francis Bacon, Lord Verulam, that "he that hath wife and children giveth hostages to fortune." Most small cash loans advanced to individual men are really made through these borrowers to a phalanx of wives and children. The small loans problem in the United States is a family problem. It is a riddle of family financial health; of social standing in the esteem of relatives and neighbors; of pride and the will to carry on with the home. And it is this consideration that makes the social aspects basic in any analysis of the broad riddle.

- A.B., rgo4, LL.B., 1907, Harvard University. Professor of Social Service and Director of the Curriculum in Social Work of the Graduate Institute of Public and Social Administration, University of Michigan. Author of numerous articles in the field of consumer credit. 
It may not be amiss in this short exploration to note the importance of the family as an institution in human society, since this premise is fundamental in much of the discussion that follows. Familiar and unspectacular, the family hearth is in danger of some contempt from a hurrying, bustling, work-a-day world. We look with some complacency upon a showing of one divorce in every six marriages. We are not more alarmed at one sterile union in every six matings. Yet these startling evidences of economic and social insecurity of family status are of grave concern to the future of our people. Society, in its more considerate moments, knows this fact full well. As a people we throw all possible protection about the breeding lair in which man rears his young to a state of competence; to which fact our elaborate body of law on the topics of marriage and divorce, of alimony, of parent and child, bears abundant testimony.

\section{Family Credit a Necessity}

In this appraisal of the social and economic aspects of the small loans problem it is the purpose, first, to examine the alleged necessity for cash credit to the householder of small means and then to indicate the effect of such borrowings upon the financial health and the social position of the family.

And first as to the justification for the small loan business at all. Is credit necessary to the American citizen? If he were man enough to follow old Ben Franklin's admonitions about thrift, could he not pay his way and be forehanded enough to avoid the need of credit? Since the dawn of recorded time the man who must secure leniency and concession from his creditors has stood forth a prominent figure in human affairs. The long history of usury, referred to elsewhere in this symposium, is eloquent of poverty in its cry for alleviation. And today, as always, the poor man must have credit. Upon this constant and universal necessity rests the long life and perennial vigor of the loan shark. Upon it is hypothecated the slowly developing realization of society-that the borrowing family must be protected in its helplessness. Upon it too is based the new, law-abiding group of small loans companies who seek to extend credit for a reasonable return.

\section{The Economic Background of Borrowing}

Studies made for the National Resources Board show such data as give a general picture of family incomes in the United States. Following this data, if we take a broad survey of American family conditions, it will be discovered that there are some $29,000,000$ such units in our population. Statistically they average abbut four persons per unit, but if all the childless couples living in a family unit were to be left out of the reckoning it would be found that those containing children are increased appreciably in size. Let us view these circumstarices always in view of the question, does this family really need credit? A study made by Spurgeon Bell shows that gainfully employed persons make up about $43 \%$ of the population of the United States. ${ }^{1}$ By

${ }^{1}$ See Bell, Productivity, Wages and National Income (Brookings Inst., 1940) 7. 
and large these are the persons who work at jobs for corporations. They are the wage earners of America. They are the occupants of the modest households of the nation. They are also the cash loan borrowers in the main. There are some 56,000,000 in this army of job workers. Their dependents number some 70,000,000. Altogether, gainfully employed workers and their families make up $96 \%$ of the total population. ${ }^{2}$

About one fifth of the workers are self-employed, of whom 6,500,000 are farmers on their own land. Some $8.5 \%$ of our gainfully employed workers are professional and managerial employees, commanding relatively high pay. They fall almost uniformly in the higher income brackets now to be discussed. Wage workers and lowsalaried employees total a little over $30 \%$ of the whole population and represent families which are receiving $\$ 1500$ a year or less for total family income. It is a further finding of Bell's study that the wage earning group in our population holds at a stable percentage and has shown only slight change in the last 60 years. By contrast, the self-employed group has declined. Farmers, who represent the smallest single group among cash loan borrowers, have fallen from $28 \%$ to $12 \%$ of the total working population since $1880 .^{3}$ And if we turn our attention to changes within the wage earning group we discover that industrial wage earners, who totaled $29 \%$ of all gainfully employed workers in 1880 , increased by 1920 to $37 \%$. Since 1920 they have declined, but in 1939 still stood at $34 \%$.

The typical wage earner's household is the household of the industrial laborerthe factory hand-who does a tour of labor for a corporation, drawing a wage that is partially protected as to rates of pay, but completely insecure as to yearly amount. That is to say, if he does the work at the agreed rate he will receive the wages; but unless his mental and physical competence hold him at the bench or the machine, and the job itself holds, he will get nothing. He cannot, like the farmer, turn to the garden and the storage bin for food. Failing savings or a pay slip he must have credit or else charitable relief; without one or both of which he and his wife and children are destitute.

If we scrutinize the wage rates in relation to hours, in terms of total wages, we shall find that the gains secured by labor in hourly rates of pay have been much more than offset by the decrease in weekly pay due to the reduced hours worked. And annual wages have declined even more than weekly wages. In manufacturing industries, at least, relatively full-time work was characteristic of the 1920's, but undertime was the rule in the $30^{\prime}$ 's, even on the basis of a standard work-week already. reduced by some $15 \%{ }^{4}$ As a general observation, the total wages paid to workers in the major industrial divisions combined, fell off materially in the period between 1923-24 and $1936-37 .^{5}$ Labor's greatest gain in this interval of intensive industrialization has been in leisure, a "commodity" which cannot be eaten, and. can seldom be

'Ibid.; and see Wolman, Hours of Work'in American Industry, Bull. No. 7r, Nat'l. Bur. Econ. Research (1930) at 17-18.

B BeLI, op. cit. supra note I, at 172 .
} 
turned to income. Studies under the auspices of the National Industrial Conference Board substantiate the general observations here set out. ${ }^{6}$

As might be expected from these limitations upon the worker's earning power, the total figures for family income in the United States are far from gratifying. The bottom third of all the families in our population receive less than $\$ 780$ a year total income. The mean income for this group in $1935-36$ was $\$ 47 \mathrm{x}$. Some $5,900,000$ individuals in this group lived in families of two or more persons and received no public relief during the year. About one million of those who received no relief lived in cities of 100,000 population or over. Some $30 \%$ of this third of our nation received some sort of public or charitable relief during that year. The middle third of the nation includes $13,000,000$ families and single individuals who in $1935-36$ received from $\$ 780$ to $\$ 145^{\circ}$ in total income. Only about $13 \%$ of this group received some charitable relief during the year. This third took in $24 \%$ of the national income and received an average or mean income of $\$ 1076$. Compared with the bottom third, this middle third contained twice as many who lived in large cities. The top third includes all incomes from $\$ 1450$ up. They received $66 \%$ of the national income and showed an average or mean just under $\$ 3000$. The non-relief wage earners in this third receive relatively low incomes, the average being $\$ 2100$.

The study from which these figures have been taken calls attention properly to the difference between dollar totals and real income, especially when distinguishing between farmers and city dwellers. It is all too apparent, however, that a minimum standard of health and decency would be hard, if not impossible, to attain at much below the upper third of family income. Indeed studies of the cost of living point to a fairly definite minimum requirement for family subsistence. It is estimated after exhaustive analysis that the lowest subsistence budget upon which the average family living in an American city can subsist is $\$ 1260$, on prices as of 1936 and that something over $\$ 1$ joo must be reached if a fair standard of health and decency is to be attained. At 1929 prices, a Brookings Institution study estimates $\$ 2000$ as a minimum income for the supply of only basic necessities. ${ }^{7}$ And this in face of the fact that not many over three millions of all the non-relief families living in large cities are found to be above the $\$ \mathrm{I}_{45}$ income level. The evidence tends further to show that the average income of these fortunates is not many dollars above the minimum of their third.

One further aspect of family income figures is worth noting. It relates to the family where there are several children. The average income of non-relief families does not rise in consonance with increase in numbers within the unit. Thus the average income of non-relief single women was found in the report of the National Resources Committee of August 1938, already quoted extensively, to be \$r188; for single men \$133; but only \$rgo5 for families of five and six persons. A fourth of

\footnotetext{
- See Martin, National Income in the United States, 1799-1938 (1939) N. I. C. B. Study No. 241.

'Leven, Mouzton and Wareurton, America's Capacity to Consume (1934) 56.
} 
all our non-relief families are two-person units; two fifths are three- and four-person units.

The best collateral for cash lending to the family is a sense of family security. We have recounted some determinants of this financial health of the American family as they bear upon this sense of security. There are three other elements of insecurity which call for notice. The first of these is physical health in its bearing upon the breadwinner's ability to carry on. The second is the physical setting in which the family lives. And the third is the degree of opportunity which the wage earner now possesses for the earning of income. And first as to physical health.

\section{Illness a Major Threat to Economic Competency}

Modern science and improved medical practice have brought many diseases under control. The public health was never better. Yet sickness is widespread and resulting disabilities to wage earners are a heavy detriment. The fear of illness, and incapacity for work as a result of it, constitute heavy elements in the complex of insecurity which dogs the wage earners of America.

Sickness is associated closely with low standards of living; and low standards are associated intimately with low income. In 1935 the United States Public Health Service, collaborating with the Millbank Foundation, made a study of 12,000 families in poorer sections of ten industrial areas. Of these families $66 \%$ had incomes below $\$ 1200 ; 32 \%$ less than $\$ 600$. The illness rate among those hardest hit by the depression was $56 \%$ above the rate for the more fortunate; and sickness was more prevalent among the "new poor" due to unemployment than among the chronic poor. Families with no employed worker rated $48 \%$ higher in the incidence of sickness than those with a full-time worker. It was $14 \%$ higher than among those with a part-time worker. ${ }^{8}$

In a California study covering more than 42,000 schędules it was found that among 18,316 known incomes the average medical bill was $\$ 79.25$ for the year per family, on which $\$ 6 \mathrm{I} .13$ was paid, leaving $\$ 18.12$ still owing. Incomes below $\$ 500$ failed by $\$ 15.16$ to meet the average $\$ 33.33$ bill. Those between $\$ 500$ and $\$ 1000$ a year owed $\$ 17.6 \mathrm{I}$ on a $\$ 43 . \mathrm{i} 3$ bill. Between $\$ 1000$ and $\$ 1200$ it was $\$ 16.83$ owing on a $\$ 49.98$ charge. Between $\$ 1200$ and $\$ 1500$ it was $\$ 18.65$ owing on a $\$ 72.29$ bill; between $\$ 1500$ and $\$ 2000$ it was $\$ 20.82$ on an $\$ 88.78$ account. And on incomes between $\$ 2000$ and $\$ 2500$ it rose to $\$ 22$ on a $\$ 119.95$ bill. Further studies tend to show that workers from families with incomes below $\$ 1200$ lose 8.9 days work from sickness; while those between $\$ 1200$ and $\$ 2000$ lose only 5.7 days. ${ }^{9}$ It is to be noted that while there is marked inability to meet medical costs, at least below the $\$ 2500$ level of income, the predominant fact from these data is that the deeper the poverty the greater the reluctance to call the doctor. Some $90 \%$ of the members of families receiving less than $\$ 1200$ a year receive no dental care whatever. Among incomes above $\$ 10,000$ the

\footnotetext{
${ }^{8}$ Nat'l. Health Council, Health Facts (1938) 3.

- Interdepartmental Committee to Coordinate Health and Welfarc Activities, Report, H. R. Doc. No. 120,76 th Cong., Ist Sess. (1938).
} 
percentage is only 40 . In a recent survey of 9,000 families living in 130 communities in $x 8$ states it was concluded that the services from physicians covers only $43 \%$ of that considered essential for adequate care: hospital care reached only $25 \%$ of the standard and dental care only $24 \%$. As a broad statement, a large proportion of our population, in any one year, either do not receive the care necessary to protect their health or else they are hopelessly burdened by the costs. ${ }^{10}$

\section{Bad Housing Leads to Insecurity in Home and Family}

Turning to the second hazard to a well founded sense of security-the housing of the American family, it is an alarming fact, not too well known, that a full third of all families in the United States live in sub-standard dwellings. Nor is the term "sub-standard" as here used a mere expression of failure to meet some ideal level of pleasant living, set up like a straw man to be knocked down in favor of government entry, into the housing industry. Rather it means a dwelling which by reason of general dilapidation, over-crowding, faulty construction arrangement, lack of ventilation, light, or sanitation facilities, or any combination of these factors, is detrimental to safety, health, or morals. ${ }^{11}$ In short, it is a dwelling whose inhabitants, for fault in their dwelling place, cannot live at a minimum standard of health and decency. Pride of family and a sense of cleanliness and decency are vastly discouraged by broken ceilings and walls; by sagging sills, dingy and broken sashes, chronic leaks in the roof and leaky, ill-smelling plumbing, with the necessity of a constant but losing war upon rats, roaches and other vermin. When, to these conditions, are added the crowding of many families into quarters intended for one or at most two; so that the only toilet stands exposed in a corridor, used in common, it would seem to be the exception rather than the rule that the citizen can take pride in his home and family and can stand before his creditors clear eyed. Yet, data covering 5,000,000 residential buildings in 204 urban centers throughout the United States, which buildings contained more than eight million households, show that more than a million homes exhibited such serious structural defects as to be unsafe and unfit for habitation. About one fifth of the total-more than $\mathrm{r}, 600,000$ homes-were without private bathing facilities and I,200,000 had no indoor water closets.

About 850,000 families were doubled up in quarters too cramped for decent use. Over I,300,000 homes were crowded-that is, contained more than one person per 'room. ${ }^{12}$ It is the claim of the United States Housing Authority that "even before this depression commenced over 10,000,000 families, or more than 40,000,000 people, were subjected to housing conditions that did not adequately protect their health and safety." 13 Nor does the record of dwelling construction during the last decade give much reassurance of improvement in the housing of families of small income. The federal authority estimates, on a basis of research data, that only $8 \%$ of all dwellings

${ }^{10}$ Foster, Doctors, Dollars and Disease, Pub. Affairs Pamphlets No. 1o (Rev. ed. 1938).

${ }^{11}$ See United States Housing Act of 1937, 50 Stat. 88, 42 U. S. C. \$1 401 (Supp. 1940).

${ }^{12}$ U. S. Housing Auth. Bull., What the Housing Act Can Do for Your City (1938).

${ }^{15}$ Id. at 3. 
constructed in the United States between 1929 and 1935 were within the reach of the $65 \%$ of our families who had annual incomes under $\$ 1500$. There were over $3,500,000$ of these families and only 21,351 dwellings that they could afford to live in were built in seven years. At the same time it was estimated that 3,000,000 new dwellings would have been required merely to house additional families at the occupancy standard of 1930 , leaving no allowance for demolition. ${ }^{14}$

The dilapidated condition of such a large number of the dwellings in which our low-income families now live may not directly and immediately affect the householder's need for credit, but by forming, as it does, a drag anchor upon his physical and mental capacity to carry on-his drive to reach his most eligible and best estate as a citizen, it has a powerful effect upon his standard of living and his eligibility as a borrower. It discourages family pride. It fills the tenant with a sense of insecurity and inadequacy. It gives him a strong tendency not to care; and in the end to fall back upon the public bounty for his support, wherever the public is willing to give it. The close interrelationship between bad housing on the one hand and sickness, vice and law-breaking on the other is indicative of its social damage and its discouragement to the breadivinner's drive for economic independence.

Real estate inventories and surveys in the field of health and crime demonstrate the brotherhood of these influences. A simple test applied to any urban area in the United States will show it graphically. If, for instance, a spot map of such an area showing the locus of delinquency, juvenile and adult, be placed upon the wall; and beside it another spot made of the same area showing the locus of all cases of tuiverculosis; and still a third showing the number of health and police calls made during a year; with a final map showing substandard residential districts; these maps will reveal similar patterns. The area of bad housing is the area of excessive crime, of sickness, of substandard conduct. These conditions are manifestations of unwholesome social relationships, of excessive frequency in crime; of greatest frequency of sickness, all as a superstructure upon economic inadequacy.

These forces point toward dependency, but they also reveal the need of all legitimate aids to economic self-support, the greatest of which is the opportunity and ability to get and hold a job, and the second of which is the tide-over through times of stress which is represented by credit. Most assuredly the argument for public assistance is only the final stage of the plea for credit-necessity drives its victims from the one into the other.

\section{Unemployment the Greatest Menace to Family Security}

The American worker in industry finds it increasingly hard to get and hold a job. In hard times this is explained by the slowing down of manufacturing. In good times much is said about a growing technical labor surplus. The automatic machine -man's greatest material accomplishment, in all probability-is accused of stealing

11. Id. at 8 . 
away his old job without giving him a new one. Sometimes immigration and the usurping of his place at the bench by newcomers from foreign lands is said to be the cause. Let the cause or causes be what they may, there are either too many workers for the volume of production now practicable or else there is too little production for the common well being. By the second year of the depression of 1930 to 1936 there were millions of workers out of a job. Estimates placed the total variously at $10,000,000$ to $16,000,000$. Public relief was extended to some $16,000,000$ workers and enough of their dependents to make a grand total in the neighborhood of $40,000,000$ on relief.

And now, with business markedly on the up-swing, the estimates of the unemployed run as high as $10,000,000$ workers. The next noteworthy fact in the situation of the unemployed is that in 1929 when production was at its highest peak in our history it was estimated that employment totaled only about nine-tenths full time. ${ }^{15}$ Business is now booming, yet, as always at this time of the year, the total of men on public relief is mounting by hundreds of thousands. The problem of employment for these workers rests not alone upon the slowing down of industry.

By what means so many American families have fallen to this level of mere subsistence is beyond the scope of this article. It may be enough to point out that the American working man and his family are undergoing a major readjustment to a new economic and industrial world. In the last century he lived for the most part in a cottage out on the land. He tilled the soil. He made his living out of the products of the soil and bartered for his imports. Though he was often poor in assessable values, he had relatively little use for money.

But in this century he lives in ever-widening population swarms and works for a daily wage. This wage has not the certainty of the food produced on the farm. The job, even when steady, produces dollars of varying size-unlike the corn and potatoes comparatively so regular from season to season. The workingman's dollar has a way of depending upon world finance to tell it how much food it will buy. Then too the automatic machine, in its vast development, calls for fewer and fewer workers, relatively speaking; and population increase produces more and more workers seeking jobs. The result is an ever-mounting technical labor surplus, let the times be ever so prosperous.

The constant trend of our times is toward a gravitation of income into the hands of a very small percentage of the people with a thinner and thinner spread of income to a broadening majority in the mass. Economic surveys bear witness to the fact that the average American family cannot maintain a standard of health and decency on the income received, even in our most prosperous times. Necessary expenditures exceed income, and emergencies can be met only by credit or by charity. It is no surprise, therefore, that consumer credits now outstanding probably exceed $\$ 7,000$,

\footnotetext{
10 Watson, Economic Backgrounds of the Relief Problem (1937) 103.
} 
$000,000,{ }^{16}$ nor that individual cash loans in small amounts total more than $\$ 650,000,000$ a year! ${ }^{17}$ Outstandings on small cash loans aggregated $\$ 44 \mathrm{x}, 700,000$ in June of $1940^{18}$

If it can be borne constantly in mind that fully two thirds of our American families do not, as a whole, lay up savings against emergent and unusual expenditures; and that at least a third of them have incomes so low that they are obliged to live beyond their means in order to subsist; it is then possible to appreciate the necessity which constantly besets these families to tide over emergent outlays by extensions of credit. From whatever angle they be viewed, all economic and social factors entering into this problem of small cash loans, they all tend strongly to establish the conclusion that credit is not merely expedient-it is a necessity.

Having gone so far, it is only logical to assume that where credit must be extended if self-support is to be maintained, then the means for providing that credit must also be realized. Aforetime it was the opprobrious money lender. Today it is the legitimate lender, brought into being by one of America's greatest advances in social legislation, the Uniform Small Loan Law. The loan shark is a predatory invader in a field of social and economic necessity. From all angles he is a menace, who will be present, out of the necessities of the situation, unless and until a sound program of cash credit extension can be set up with legal sanctions and safeguards against him. Such a program has in fact been set up and is now in effect in most of our states. Other articles in this symposium will set out this plan and its development.

\footnotetext{
${ }^{16}$ See Consumer Credit, Proceedings of a Conference, Michigan Business Papers No. 9 (March, 1940) at p. 21 .

${ }^{17}$ Neifeld, Personal Finance Comes of Age (1939) 17.

${ }^{18}$ Personal Finance Companies-Instalment Loans to Consumers (Credit Analysis Unit, Marketing Research Div., U. S. Dep't Com., 1940).
} 